\title{
ОБґ'РУНТУВАННЯ АНТИМІКРОБНОЇ ЕФЕКТИВНОСТІ АПЛІКАЦІЙНИХ БІОНАНОКОМПОЗИТІВ ДЛЯ ЛІКУВАННЯ ОПІКОВОЇ ІНФЕКЦІЇ, СПРИЧИНЕНОЇ S. AUREUS TA P. AERUGINOSA
}

\author{
Г. М. Чернякова ${ }^{1}$, В. В. Мінухін ${ }^{1}$, Є. П. Воронін ${ }^{3}$, Д. В. Мінухін ${ }^{2}$ А. Г. Краснояружський ${ }^{2}$ \\ Д. С. Єфрімов ${ }^{1}$, К. В. Пономарьова ${ }^{2}$ \\ ${ }^{1}$ Харківський національний медичний університет, \\ ${ }^{2}$ Інститут загальної і невідкладної хірургії імені В. Т. Зайцева НАМН України, \\ ${ }^{3 / н с т и т у т ~ х і м і і ̈ ~ п о в е р х н і ~ і м е н і ~ О . ~ О . ~ Ч у и ̆ к а ~ Н А Н ~ У к р а і ̈ н и, ~ м . ~ Х а р к і в ~}$

\section{SUBSTANTIATION FOR ANTIMICROBIAL EFFICACY OF APPLICATIONAL BIONANOCOMPOSITS IN THE TREATMENT OF THE BURN INFECTION, CAUSED BY S. AUREUS AND P. AERUGINOSA}

\section{G. M. Chernyakova ${ }^{1}$, V. V. Minukhin ${ }^{1}$, E. P. Voronin ${ }^{3}$, D. V. Minukhin², A. G. Krasnoyaruzhskyi², D. S. Efimov ${ }^{1}$, K. V. Ponomaryova ${ }^{2}$}

${ }^{1}$ Kharkiv National Medical University, 2Zaytsev Institute of General and Urgent Surgery, ${ }^{3}$ Chuyko Institute of Chemistry of Surface, Kharkiv

\begin{abstract}
Реферат
Вивчено антимікробну активність експериментальних протимікробних нанокомпозитів щодо музейних і клінічних штамів $\mathrm{S}$ aureus та P. aeruginosa методом серійних розведень в бульйоні та щільному поживному середовищі. Всі клінічні штами S. aureus виявилися чутливими до композитів з левофлоксацином та резистентними до сумішей з сульфаметоксазолом; щодо штамів Р. aeruginosa, $90 \%$ клінічних ізолятів були чутливими до сумішей з левофрлоксацином, $65 \%$ - з сульфаметоксазолом.

Ключові слова: опікова інфекція; клінічні штами збудників; антимікробна активність; резистентність.

Abstract

Antimicrobial activity of experimental antimicrobial nanocomposits, concerning the museum and clinical strains of $S$. aureus and $P$. aeruginosa, using the batch dilution method in bouillon and thick nutritious environment, was studied. All clinical strains of $\mathrm{S}$. aureus have appeared sensitive to composits with levofloxacine and resistant to mixtures with sulfametoxazol; and as for strains of P. aeruginosa, $90 \%$ clinical isolates were sensitive towards mixtures with levofloxacine, and $65 \%$ - with sulfametoxazol.

Keywords: the burn infection; clinical strains of causative agents; antimicrobial activity; resistance.
\end{abstract}

Питання виникнення, профілактики та лікування опікової ранової інфекції є важливою проблемою сучасної медицини. Резистентність мікроорганізмів до антибактеріальних препаратів ускладнює вирішення цього завдання. Незважаючи на досягнуті успіхи, летальність потерпілих за глибоких поширених опіків, інфікованих госпітальними штамами мікроорганізмів, досягає 40$70 \%[1]$.

Синьогнійна паличка та золотистий стафілокок є одними з основних аерофільних збудників ранової опікової інфекції [2]. Вірулентність і патогенність цих мікроорганізмів зумовлюють тривалий і тяжкий перебіг гнійного процесу в опіковій рані, а виникнення мультирезистентності до антибіоти- ків зумовлює додаткові ускладнення [3]. При етіотропній терапії опікової ранової інфекції велику увагу приділяють місцевим методам лікування, вони передбачають використання препаратів, що мають протизапальну, антимікробну, детоксикаційну та регенеруючу дію. У зв'язку з цим, актуальним $€$ пошук і експериментальне обгрунтування використання нових високоефективних засобів місцевого лікування опікових ран та інфекційних ускладнень [4].

В останні роки інтенсивно розвивався новий підхід до лікування ран - вульнеросорбція. Метод передбачає видалення ексудату, мікроорганізмів та їх токсинів з рани за допомогою сорбційних матеріалів. За даними літератури, перспективною $є$ розробка комплексного препарату
- аплікаційного сорбенту, здатного не тільки видаляти ексудат і рідину з опікової рани, а й такого, що мав би протимікробні властивості, пригнічуючи процеси запалення та активізуючи регенерацію ушкоджених тканин у рані [5].

Мета дослідження: проаналізувати антимікробну активність нових біонанокомпозитів на основі нанорозмірного кремнезему 3 іммобілізованими на його поверхні антибактеріальними сполуками щодо клінічних штамів S. aureus та P. aeruginosa.

\section{МАТЕРІАЛИ I МЕТОДИ \\ ДОСЛІДЖЕННЯ}

У потерпілих з опіками, яких лікували у Харківській міській клінічній лікарні швидкої та невідкладної медичної допомоги ім. проф. 
Таблиця 1. Склад досліджуваних нанокомпозитів

\begin{tabular}{|c|c|c|c|c|c|c|c|}
\hline \multirow{2}{*}{ № } & \multirow{2}{*}{ Компоненти } & \multicolumn{6}{|c|}{ Склад } \\
\hline & & $r$ & $\%$ до $\mathrm{SiO}_{2}$ & $r$ & $\%$ до $\mathrm{SiO}_{2}$ & $r$ & $\%$ до $\mathrm{SiO}_{2}$ \\
\hline \multirow{6}{*}{1} & Нанокремнезем & 1 & - & 1 & - & 1 & - \\
\hline & Сульфаметоксазол & 0,05 & 5 & 0,1 & 10 & 0,15 & 15 \\
\hline & Хлорофіліпт & 0,01 & 1 & 0,01 & 1 & 0,01 & 1 \\
\hline & (2\% розчини в олії) & $(0,5)$ & $(50)$ & $(0,5)$ & (50) & $(0,5)$ & $(50)$ \\
\hline & Нітрат срібла & 0,01 & 1 & 0,01 & 1 & 0,01 & 1 \\
\hline & Хітозан & 0,06 & 6 & 0,06 & 6 & 0,06 & 6 \\
\hline \multirow{6}{*}{2} & Нанокремнезем & 1 & - & 1 & - & 1 & - \\
\hline & Левофлоксацин & 0,0005 & 0,05 & 0,001 & 0,1 & 0,005 & 0,5 \\
\hline & Хлорофіліпт & 0,01 & 1 & 0,01 & 1 & 0,01 & 1 \\
\hline & (2\% розчин в олії) & $(0,5)$ & $(50)$ & $(0,5)$ & (50) & $(0,5)$ & $(50)$ \\
\hline & Нітрат срібла & 0,01 & 1 & 0,01 & 1 & 0,01 & 1 \\
\hline & Хітозан & 0,06 & 6 & 0,06 & 6 & 0,06 & 6 \\
\hline
\end{tabular}

О. І. Мещанінова та клініці Інституту загальної та невідкладної хірургії імені В. Т. Зайцева НАМН України, для дослідження забирали виділення з ран, а також кров. Бактеріологічні дослідження проведені відповідно до Наказу МОЗ України № 167 від 05.04.2007 р. [6, 7]. Для визначення антибіотикочутливості штамів використані набори дисків 312 антибактеріальними препаратами: пеніцилін, оксацилін, еритроміцин, левофлоксацин, ципрофлоксацин, ванкоміцин, гентаміцин, лінкоміцин, амікацин, цефтазидим, цефепім, меропенем, іміпенем (виробництва ТОВ «Аспект», Київ). Антибактеріальну активність протимікробних сумішей визначали методом серійних розведень в бульйоні (щодо музейних штамів S. aureus ATCC 29213 та P. aeruginosa ATCC 27853) та щільному поживному середовищі (щодо 40 клінічних штамів S. aureus та $20-\mathrm{P}$. aeruginosa) [6, 8].
Таблиця 2. Діаметр зон затримки росту досліджуваних референсштамів, мм

\begin{tabular}{|l|c|c|c|}
\hline \multicolumn{1}{|c|}{ Препарат } & $\begin{array}{c}\text { Вміст препарату } \\
\text { в диску, мкг }\end{array}$ & $\begin{array}{c}\text { S. aureus } \\
\text { (ATCC 25923) }\end{array}$ & $\begin{array}{c}\text { P. aeruginosa } \\
\text { (ATCC 27853) }\end{array}$ \\
\hline Бензилпеніцилін & 6 (10 ОД) & $28(\mathrm{~S})$ & - \\
\hline Оксацилін & 1 & $22(\mathrm{~S})$ & - \\
\hline Еритроміцин & 15 & $27(\mathrm{~S})$ & $21(\mathrm{~S})$ \\
\hline Левофлоксацин & 5 & $26(\mathrm{~S})$ & $28(\mathrm{~S})$ \\
\hline Ципрофлоксацин & 5 & $25(\mathrm{~S})$ & - \\
\hline Ванкоміцин & 30 & $18(\mathrm{~S})$ & $20(\mathrm{~S})$ \\
\hline Гентаміцин & 10 & $22(\mathrm{~S})$ & $24(\mathrm{~S})$ \\
\hline Амікацин & 30 & $23(\mathrm{~S})$ & $28(\mathrm{~S})$ \\
\hline Цефтазидим & 30 & $18(\mathrm{~S})$ & $32(\mathrm{~S})$ \\
\hline Цефепім & 30 & $25(\mathrm{~S})$ & $25(\mathrm{~S})$ \\
\hline Меропенем & 10 & $31(\mathrm{~S})$ & \\
\hline Іміпенем & 10 & - & \\
\hline
\end{tabular}

Примітка. (S) - чутливі.

В експерименті використані 6 дисперсного нанокремнезему, хлозразків композитів, виготовлених у рофіліпту, кукурудзяної олії, нітрату лабораторії модифікування поверх- срібла та хітозану. У 3 нанокомпозині оксидів Інституту хімії поверхні тах додатково містилося відповідно ім. О. О. Чуйка НАН України. Всі вони 5\%, 10\% і 15\% сульфаметоксазолу, у 3 містили однакову кількість високо- - 0,05\%, 0,1\% і 0,5\% левофлоксацину

Таблиця 3. Антибіотикочутливість клінічних штамів S. aureus та P. aeruginosa, \%

\begin{tabular}{|c|c|c|c|c|c|c|c|}
\hline \multirow{2}{*}{ Препарат } & \multirow{2}{*}{$\begin{array}{c}\text { Вміст препарату } \\
\text { в диску, мкг }\end{array}$} & \multicolumn{3}{|c|}{ S. aureus $(n=40)$} & \multicolumn{3}{|c|}{ P. aeruginosa $(n=20)$} \\
\hline & & $\mathrm{S}$ & $\mathrm{M}$ & $\mathrm{R}$ & $S$ & $M$ & $R$ \\
\hline Бензилпеніцилін & 6 (10 ОД) & 30 & - & 70 & - & - & 100 \\
\hline Оксацилін & 1 & 100 & - & - & - & - & 100 \\
\hline Еритроміцин & 15 & 5 & 90 & 5 & - & - & 100 \\
\hline Левофлоксацин & 5 & 100 & - & - & 30 & & 70 \\
\hline Ципрофлоксацин & 5 & 80 & - & 20 & 20 & & 80 \\
\hline Гентаміцин & 10 & 100 & - & - & 40 & 10 & 50 \\
\hline Амікацин & 30 & 70 & 20 & 10 & 50 & 10 & 40 \\
\hline Цефтазидим & 30 & 90 & 5 & 5 & 50 & - & 50 \\
\hline Цефепім & 30 & 100 & - & - & 50 & - & 50 \\
\hline Меропенем & 10 & 70 & 20 & 10 & 30 & 20 & 50 \\
\hline Іміпенем & 10 & 80 & 15 & 5 & - & - & 100 \\
\hline
\end{tabular}

Примітка. $\mathrm{S}$ - чутливі; $\mathrm{M}$ - помірно чутливі, $\mathrm{R}$ - стійкі. 
Таблиця 4. Результати експериментальної перевірки активності комбінованих протимікробних сумішей 3 левофлоксацином щодо музейних штамів S. aureus (ATCC 29213) та P. aeruginosa (ATCC 27853)

\begin{tabular}{|c|c|c|c|c|c|}
\hline \multirow[b]{2}{*}{ № композиту } & \multirow[b]{2}{*}{ Мікроорганізм } & \multicolumn{2}{|c|}{$\mathrm{MIK}, \mathrm{Mr} / л$} & \multicolumn{2}{|c|}{ МБК, Мг/л } \\
\hline & & $\begin{array}{c}\text { антибактеріальної } \\
\text { суміші }\end{array}$ & $\begin{array}{l}\text { у перерахунку на } \\
\text { левофлоксацин }\end{array}$ & $\begin{array}{c}\text { антибактеріальної } \\
\text { суміші }\end{array}$ & $\begin{array}{c}\text { у перерахунку } \\
\text { на левофлоксацин }\end{array}$ \\
\hline \multirow{2}{*}{$1^{*}$} & S. aureus (ATCC 29213) & 1500 & 0,45 & 6250 & 1,85 \\
\hline & P. aeruginosa (ATCC 27853) & 6250 & 1,85 & 12500 & 3,7 \\
\hline \multirow{2}{*}{$2^{*}$} & S. aureus (ATCC 29213) & 750 & 0,45 & 3125 & 1,85 \\
\hline & P. aeruginosa (ATCC 27853) & 3125 & 1,85 & 6250 & 3,7 \\
\hline \multirow[b]{2}{*}{ 3* } & S. aureus (ATCC 29213) & 190 & 0,5 & 750 & 2,25 \\
\hline & P. aeruginosa (ATCC 27853) & 750 & 2,25 & 1500 & 4,5 \\
\hline
\end{tabular}

Примітка. $\quad$ *- вміст левофлоксацину в композиті 1 - 0,05\%, 2 - 0,1\%, 3 - 0,5\%.

Таблиця 5 Результати експериментальної перевірки активності комбінованих протимікробних сумішей з сульфаметоксазолом щодо музейних штамів S. aureus (ATCC 29213) та P. aeruginosa (ATCC 27853)

\begin{tabular}{|c|c|c|c|c|c|}
\hline \multirow[b]{2}{*}{ № композиту } & \multirow[b]{2}{*}{ Мікроорганізм } & \multicolumn{2}{|c|}{$\mathrm{MIK}, \mathrm{Mr} / л$} & \multicolumn{2}{|c|}{ МБК, $\mathrm{Mr} / л$} \\
\hline & & $\begin{array}{c}\text { антибактеріальної } \\
\text { суміші }\end{array}$ & сульфаметоксазолу & $\begin{array}{c}\text { антибактеріальної } \\
\text { суміші }\end{array}$ & сульфаметоксазолу \\
\hline \multirow[t]{2}{*}{$1^{*}$} & S. aureus (ATCC 29213) & 25000 & 700 & 50000 & 1400 \\
\hline & P. aeruginosa (ATCC 27853) & 12500 & 350 & 25000 & 700 \\
\hline \multirow[t]{2}{*}{$2 *$} & S. aureus (ATCC 29213) & 12500 & 700 & 25000 & 1400 \\
\hline & P. aeruginosa (ATCC 27853) & 6250 & 350 & 12500 & 700 \\
\hline \multirow[t]{2}{*}{$3^{*}$} & S. aureus (ATCC 29213) & 6250 & 600 & 12500 & 1200 \\
\hline & P. aeruginosa (ATCC 27853) & 3125 & 300 & 6250 & 600 \\
\hline
\end{tabular}

Примітка. $\quad$ * вміст сульфаметоксазолу в композиті 1 - 5\%, 2 - 10\%, 3 - 15\%.

(табл. 1). Експериментальна частина роботи виконана на базі кафедри мікробіології, вірусології та імунології Харківського національного медичного університету. Дослідження проводили тричі. Статистична обробка результатів здійснена з використанням стандартних програм обробки даних MS Excel, BioStat LE. Достовірність результатів визначали за критерієм Ст'юдента ( $<$ 0,05).

\section{РЕЗУЛЬТАТИ}

\section{TA ÏХ ОБГОВОРЕННЯ}

На першому етапі експерименту диско-дифузійним методом визначали чутливість до антибіотиків референс-штамів S. aureus ATCC 25923 та P. aeruginosa ATCC 27853 (табл. 2) та клінічних штамів цих мікроорганізмів, виділених у потерпілих 3 опіками різного ступеня тяжкості (табл.3).

Клінічні ізоляти S. aureus були високо резистентними до пеніциліну - 70\%, до ванкоміцину та ципрофлоксацину - стійкими 20\% штамів. Штами, резистентні до оксациліну, левофлоксацину, гентаміцину та цефепіму, не виявлені. Високорезистентними виявилися госпітальні штами Р. aeruginosa. До ципрофлоксацину та левофлоксацину стійкими були відповідно 80 та 70\% штамів, до гентаміцину, цефтазидиму, цефепіму та меропенему 50\% виділених штамів. Всі клінічні штами P. aeruginosa були нечутливими до іміпенему. Можливо, це пов'язане з широким використанням препарату в останні роки при лікуванні Pseudomonas-інфекціï.

На другому етапі дослідження визначали мінімальну інгібуючу концентрацію (МІК) та мінімальну бактерицидну концентрацію (МБК) досліджуваних препаратів щодо референс - штамів S. aureus та P. aeruginosa.

Композити 1 та 2 проявили більш виражену бактерицидну дію щодо музейних штамів S. aureus та P. aeruginosa, ніж композит 3 (табл. 4 , 5). Можливо, різна стійкість грамнегативних і грампозитивних мікроорганізмів до протимікробних сумішей залежить від особливостей будови їх клітин, фізико-хімічних процесів на поверхні високодисперсного нанокремнезему та інших причин, що потребують подальшого вивчення.

Протимікробна активність сумішей 3 сульфаметоксазолом щодо музейних штамів виявилася значно меншою ( $\mathrm{p}<0,05)$, ніж сумішей з левофлоксацином, незважаючи на більший вміст активної речовини. Референс-штам P. aeruginosa був чутливим до експериментальних зразків препаратів, а суміш з 15\% вмістом сульфаметоксазолу - найбільш ефективною. Щодо штаму S. aureus, антибактеріальний ефект був достовірно меншим. Потрібні подальші дослідження цієї суміші, що може бути перспективною щодо лікування ранової інфекції, спричиненої P. aeruginosa.

Наступним етапом визначали МІК комбінованих протимікробних сумішей щодо клінічних ізолятів $\mathrm{S}$. aureus $(n=40)$ та P. aeruginosa $(n=20)$. Концентрація левофлоксацину в складі біонанокомпозиту в чашках Петрі становила від 12 до 0,05 мг/л. Bci штами S. aureus були чутливими до цих концентрацій. МІК становила $(0,353 \pm 0,57)$ мг/л. Щодо Р. aeruginosa, 2 (10\%) штами виявилися резистентними, МІК становила $(3,2 \pm 0,44)$ мг/л. Різниця з музейними штамами недостовірна ( $p>0,05)$.

Концентрація сульфаметоксазолу в складі біонанокомпозиту в чашках Петрі становила від 1800 до 28 
мг/л. За результатами експерименту 28 (70\%) штамів S. aureus виявилися нечутливими до цих концентрацій. У 30\% штамів МІК становила (450 $\pm 70,86)$ мг/л (недостовірна різниця 3 музейними штамами, р > 0,05). Щодо Р. aeruginosa, 65\% досліджуваних штамів виявилися чутливими, МІК становила $(761,54 \pm 111,05)$ мг/л, що достовірно більше, ніж музейних штамів ( $<<0,05)$.

За результатами експериментів доведено, що всі клінічні штами S. aureus, що спричинили гнійно-запальні процеси у потерпілих з опіками, були чутливими до левофлоксацину та високо чутливими до протимікробної суміші, що містила цей антибіотик. Чутливими до ле- вофлоксацину були лише 30\% штамів P. aeruginosa, при використанні левофлоксацину у складі біонанокомпозиту чутливість клінічних ізолятів збільшилася до 90\%.

Можна припустити, що підвищенню антибактеріальної активності левофлоксацину сприяли компоненти, що входять до складу суміші. Незважаючи на невисоку антибактеріальну активність суміші 3 сульфаметоксазолом щодо клінічних штамів S. aureus, iii ефективність щодо госпітальних штамів P. aeruginosa свідчить про перспективність застосування у хворих при рановій Pseudomonas - інфекціï в умовах стаціонару.
Підхід, оснований на наданні сорбентам специфічних властивостей шляхом іммобілізації на іх поверхні різних лігандів і лікарських субстанцій, є перспективним. Він дозволяє зменшувати або навіть усувати негативний вплив на організм цих субстанцій. 3 використанням такого підходу досить швидко, на основі вже існуючих препаратів, можна створювати профілактичні й лікувальні комплексні препарати з більшою ефективністю.

Перспективи подальших досліджень: вивчення ранозагоювальних властивостей сумішей на моделі опікової ранової інфекції in vivo.

\section{REFERENCES}

1. Peck MD. Epidemiology of burns throughout the world. Part I: Distribution and risk factors. Burns. 2011;37(7):1087-100.

2. Hussien IA, Habib KA, Jassim KA. Bacterial Colonization of Burn Wounds. J Baghdad for Sci. 2012;9(4):623-31.

3. Church D, Elsayed S, Reid O, et al. Burn wound infections. Clin Microbiol Rev. 2006;2(19):403-34.

4. Alekseev AA, Bobrovnikov AE, Krutikov MG. Mestnoe ispolzovanie antimikrobnykh sredstv dlya lecheniya ozhogovykh ran. Available from: http://combustiolog.ru/journal/mestnoe-ispol-zovanie-antimikrobny-h-sredstv-dlya-lecheniya-ozhogovy-h-ran/. [In Russian].
5. Korobko VM, Vorobeva OA, Melnikova NB. Analiz komponentov protivoozhogovogo poroshka naruzhnogo primeneniya s 5-nitrofuralom i tsitokhromom. International journal of applied and fundamental research. 2015;9:322-8. [In Russian].

6. Nakaz MOZ Ukrainy № 167 vid 05.04.2007r. Pro zatverdzhennia metodychnykh vkazivok «Vyznachennia chutlyvosti mikroorhanizmiv do antybakterialnykh preparativ». Kyiv. 2007. 52 c. [In Ukrainian].

7. Khoult D, editor. Opredelitel bakteriy Berdzhi. 9 izdanie. Moskva: Mir; 1997. 800 s. [In Russian].

8. Volyanskiy YuL. Biologicheskaya kharakteristika i mikrobiologicheskaya identifikatsiya nefermentiruyushchikh gramotritsatel'nykh bakteriy. Uchebnoe posobie. Kharkov. 2010. 47 c. [In Russian]. 